\title{
Model Simulasi PertumbuhanTanaman Jagung Manis Hibrida pada Jarak Tanam yang Berbeda
}

\section{(Growth Simulation Model of Hybrid Sweet Corn Plant in the Different Plant Densities)}

\author{
Ervan Ferdiansyah ${ }^{1}$, Handoko $^{2 \star}$, Impron $^{2}$ \\ (Diterima April 2018/Disetujui Mei 2020)
}

\begin{abstract}
ABSTRAK
Model jagung manis hibrida dikembangkan untuk mensimulasikan pertumbuhan dan perkembangan jagung manis hibrida pada kerapatan tanam yang berbeda. Penelitian ini membandingkan data hasil model simulasi dan data observasi aktual lapangan, yang kemudian disajikan dalam bentuk grafik. Model ini dilakukan pada enam kombinasi perlakuan antara tiga jenis jarak tanam dan dua varietas. Model simulasi membutuhkan data meteorologi (suhu ratarata, kelembapan, curah hujan, dan radiasi), data air tanah dan karakteristik tanaman. Ada lima dari enam kombinasi tanaman yang grafiknya menunjukkan bahwa model ini mampu mensimulasikan total biomassa jagung setiap minggu. Model ini mampu memperkirakan $93 \%$ dari biomassa sebenarnya dan menggambarkan pertumbuhan dan perkembangan jagung manis hibrida dengan baik.
\end{abstract}

Kata kunci: menduga biomassa, model simulasi tanaman, pertumbuhan tanaman

\section{ABSTRACT}

A sweet corn model was developed to simulate the growth and development of hybrid-sweet corn under different crop denssities. This research is comparing the data of the simulation model and the actual observation data in the field, which is then presented in graphical form. This model was conducted on six treatment combinations between three types of spacing and two varieties. The simulation model requires meteorological data (average temperature, humidity, precipitation, and radiation), soil water data, and crop chracteristics. There are five of the six plant combinations which graph show that the model is able to simulate the total maize corn biomass every week. The model was able to estimate $93 \%$ of the actual biomass and described the growth and development of hybrid-sweet corn as well.

Keywords: estimating biomass, models and simulations, plant growth

\section{PENDAHULUAN}

Jagung manis (Zea mays var. Saccharata sturt) merupakan salah satu komoditas pertanian yang disukai masyarakat di Indonesia, baik dari segi konsumsi maupun produksi. Jagung manis disukai konsumen karena dapat dijadikan berbagai makanan olahan, seperti jagung bakar, jagung rebus, campuran sayur, dan aneka camilan. Sementara itu, dari segi produksi, jagung manis juga disukai petani karena dapat dipanen lebih cepat dengan harga jual yang tinggi.

Jagung hibrida berpotensi untuk memenuhi permintaan masyarakat yang tinggi terhadap jagung manis. Menurut Pusat Kajian Hortikultura (2011), permintaan masyarakat Indonesia akan sayuran, termasuk jagung manis, ialah sekitar 87.336 ton. Jenis jagung hibrida

1 Sekolah Pascasarjana, Departemen Geofisika dan Meteorologi, Fakultas Matematika dan Ilmu Pengetahuan Alam, Institut Pertanian Bogor, Kampus IPB Darmaga, Bogor 16680

2 Departemen Geofisika dan Meteorologi, Fakultas Matematika dan IImu Pengetahuan Alam, Institut Pertanian Bogor, Kampus IPB Darmaga, Bogor 16680

* Penulis Korespondensi: Email: handoko@biotrop.org menjadi salah satu strategi nasional pada tahun 2016 untuk meningkatkan produksi jagung manis ataupun jagung biasa (Kementan 2016). Jagung manis Hibrida, khususnya varietas Bonanza- $\mathrm{F} 1$, berpotensi menghasilkan produksi tongkol dengan kelobot sekitar 3334,5 ton. ha ${ }^{-1}$ (Apriyantono 2012).

Program Perluasan Areal Tanam (PAT) dan Peningkatan Indeks Pertanaman (PIP) dapat meningkatkan jumlah produksi jagung manis karena semakin luas areal tanam maka tanaman jagung yang ditanam semakin banyak sehingga produksi jagung akan meningkat. Hal tersebut hanya dapat dicapai jika tanaman jagung tumbuh optimal (Mulyani et al. 2012).

Salah satu upaya supaya jagung tumbuh optimal adalah dengan mengkaji kesesuaian unsur cuaca dan iklim untuk tanaman jagung secara kuantitatif dengan menggunakan model simulasi tanaman. Hasil pipilan kering jagung hibrida dipengaruhi oleh kondisi iklim setempat dan kerapatan tanaman (Tahir et al. 2008).

Penelitian yang dilakukan secara kuantitatif melalui model pertumbuhan tanaman mekanistik untuk tanaman jagung belum banyak dilakukan di Indonesia. Penelitian mengenai pemodelan tanaman jagung pernah diteliti oleh Suwarto (2005) dengan topik model 
simulasi tanaman jagung yang ditanam secara tumpang sari dengan tanaman umbi kayu. Selain itu, ada pula penelitian Bahar (2009) yang memodelkan tanaman jagung berdasarkan penelitian Suwarto. Kedua penelitian tersebut menyatakan bahwa model simulasi tanaman dapat menduga dan menjelaskan proses yang terjadi selama musim tanam. Akan tetapi, kedua penelitian tersebut tidak memodelkan tanaman jagung manis hibrida dengan jarak tanam tertentu.

Berdasarkan penelitian Paat (2010), sebuah model simulasi mampu mensimulasi pertumbuhan dan produksi tanaman jagung dengan biomassa total 8000 $\mathrm{kg} / \mathrm{ha}$. Selain pertumbuhan dan perkembangan model, simulasi juga dapat disusun untuk melihat neraca air tanaman selama proses penelitian sehingga dapat melihat ketersediaan air tanah yang dibutuhkan oleh tanaman (Paski 2017).

Tujuan penelitian ini adalah (i) Mengkuantifikasi respons agrometeorologi dua varietas tanaman jagung hibrida pada perlakuan jarak tanam, (ii) Menyusun model yang mampu mensimulasikan komponen pertumbuhan dan perkembangan tanaman jagung, serta (iii) Menguji kemampuan model dalam menduga pertumbuhan dan produktivitas tanaman jagung hibrida.

\section{METODE PENELITIAN}

Penelitian lapang dilakukan di Dusun Mulyasari, Desa Rancamulya, Kecamatan Patokbeusi, Kabupaten Subang pada bulan Januari-April 2017. Rancangan percobaan yang digunakan dalam penelitian ini adalah Rancangan Acak Kelompok (RAK) dengan dua faktor. Faktor pertama adalah varietas (Bonanza-F1 dan Talenta), sedangkan faktor kedua adalah jarak tanam $(70 \times 20,70 \times 30$, dan $70 \times 40)$. Dari dua faktor tersebut didapatkan enam kombinasi perlakuan yang diulang sebanyak tiga kali. Dengan demikian, terbentuk tiga kelompok percobaan. Dua kelompok digunakan untuk keperluan menyusun model dan satu kelompok digunakan untuk keperluan validasi model.

Sistem budi daya setiap perlakuan adalah sama dalam hal pemberian pupuk serta pengendalian hama dan penyakit pada setiap petak perlakuan. Dengan demikian, perbedaan yang terjadi antar-kombinasi perlakuan dianggap sebagai pengaruh perlakuan dan unsur cuaca mikro tiap petak perlakuan. Variabel yang dibutuhkan untuk menyusun model simulasi pada penelitian ini terbagi menjadi dua kelompok, yaitu variabel tanaman dan variabel cuaca. Variabel tanaman yang diamati selama masa tanam adalah biomassa total, biomassa per bagian tanaman, dan kejadian fenologi. Sementara itu, variabel cuaca yang diamati adalah radiasi matahari, suhu, kelembapan, dan curah hujan.

Radiasi matahari yang diukur dalam penelitian ini adalah radiasi global dan radiasi transmisi di bawah kanopi tanaman. Hal ini dilakukan untuk menghitung radiasi intersepsi berdasarkan neraca radiasi. Adapun alat yang digunakan untuk mengukur variabel cuaca dalam penelitian ini antara lain adalah Datalogger, sensor radiasi, sensor suhu dan kelembapan, dan alat ukur curah hujan. Selama musim tanam, pengukuran unsur cuaca dilakukan sebanyak tiga kali setiap hari pada pukul 08:00, 12:00, dan 16:00 WIB. Sementara itu, pengukuran biomassa dilakukan seminggu sekali sejak umur 4 minggu setelah tanam (MST) hingga panen (11 MST). Dengan demikian, untuk unsur cuaca didapatkan data harian, dan untuk biomassa diperoleh data mingguan.

Data cuaca dan biomassa yang terkumpul digunakan untuk melakukan parameterisasi, kalibrasi hingga validasi model. Validasi model dilakukan dengan membandingkan hasil model simulasi dengan data aktual dari pengukuran lapang, BPS, dan survei terhadap petani.

\section{Model Neraca Air Tanaman}

Model neraca air tanaman digunakan untuk mengetahui ketersediaan air tanah (KAT) selama proses penanaman. Kekeringan ataupun kelebihan air selama proses penanaman dapat dilihat dengan cara membandingkan nilai KAT dengan nilai kapasitas lapang dan titik layu permanen. Nilai KAT hari ke-i dapat di hitung menggunakan persamaan berikut:

$$
K A T_{i}=K A T_{(i-1)}+C H_{(i-1)}-E T_{c(i-1)}
$$

Nilai $E T_{c}$ diperoleh dengan mengalikan nilai evapotransiprasi standar $\left(E T_{0}\right)$ dengan nilai koefisien tanaman $\left(k_{c}\right)$, nilai $k_{c}$ yang digunakan pada tahap perkembangan awal adalah 1.26; tahap vegetatif adalah 1.72; dan tahap pembungaan hingga panen adalah 1.66 (Muamar et al. 2012). Sementara itu, untuk menghitung nilai $E T$ o digunakan metode Hamon. Adapun persamaan Hamon (Haith \& Shoemaker 1987) yang digunakan adalah sebagai berikut:

$$
E T_{0}=\frac{2.1 \times H_{t} e_{s}}{(T+273.3)}(2)
$$

Keterangan:

$\mathrm{H}_{\mathrm{t}}=$ Panjang hari

$\mathrm{T}=$ Suhu rata-rata harian $\left({ }^{\circ} \mathrm{C}\right)$

$\mathrm{e}_{\mathrm{s}}=$ Tekanan uap jenuh $(\mathrm{mb})$

\section{Model Perkembangan Tanaman}

Fase perkembangan tanaman dapat memengaruhi pembagian karbohidrat sebagai hasil fotosintesis ke organ-organ tanaman (Qadir 2012). Penelitian ini membagi fase perkembangan tanaman menjadi 8 , yaitu fase perkecambahan, fase tanaman berdaun tiga (V3), berdaun enam (V6), berdaun sembilan (V9), fase muncul bunga, pembentukan buah, fase biji susu, dan fase biji masak susu (Sumajow et al. 2016).

Laju perkembangan dan tahapan fenologi tanaman dapat didekati dengan konsep heat unit (Koesmaryono et al 1996). Konsep heat unit mengontrol fase perkembangan tanaman dengan menggunakan parameter model suhu dasar $\left(T_{0}\right)$ dan input model berupa suhu rata-rata harian selama pertumbuhan tanaman. Suhu 
dasar untuk tanaman jagung adalah $8^{\circ} \mathrm{C}$ (Kinniry et al. 1991).

Data heat unit dibutuhkan untuk menghitung nilai s, adapun nilai heat unit didapatkan dari Persamaan 3 dan nilai $s$ aktual pengukuran didapatkan dari Persamaan 4 (Handoko 1994).

$$
\begin{gathered}
H U_{\text {total }}=\sum_{i=0}^{n} T_{i}-T_{0}(3) \\
s=\sum_{i=0}^{n}\left(T_{i}-T_{0}\right) H U_{i}(4)
\end{gathered}
$$

Keterangan:

$\mathrm{HU}=$ Heat unit $\left(\mathrm{d}^{\circ} \mathrm{C}\right)$

$\mathrm{Ti} \quad=$ Suhu rata-rata harian $\left({ }^{\circ} \mathrm{C}\right)$

To = Suhu dasar tanaman jagung $\left({ }^{\circ} \mathrm{C}\right)$

$\mathrm{s}=$ Skala fase perkembangan

\section{Model Pertumbuhan Tanaman}

Menurut Handoko (1994), nilai biomassa dugaan hasil model simulasi $\left(B_{M}\right)$ didapatkan dari nilai biomassa potensial $\left(B_{p}\right)$ dan produksi biomassa potensial dihitung berdasarkan hasil kali antara efisiensi penggunaan radiasi surya (RUE) dengan radiasi intersepsi $\left(Q_{i}\right)$.

$$
\begin{gathered}
Q_{i}=Q_{s}-Q_{t}(5) \\
B_{P}=R U E * Q^{*}(6) \\
B_{M}=B_{P}(1-K g)-K_{m} B_{P} Q_{10}(7) \\
B_{X}=\eta_{x} B_{P}(1-K g)-K_{m} B_{P} Q_{10}(8)
\end{gathered}
$$

Keterangan:

$\mathrm{Qi} \quad=$ Radiasi intersepsi

$\mathrm{Q}_{\mathrm{s}} \quad=$ Radiasi di atas tajuk tanaman

$\mathrm{Q}_{\mathrm{t}} \quad=$ Radiasi yang ditransmisikan tajuk tanaman

$\mathrm{Q}_{10}=2(\mathrm{~T}-20) / 10$

$\mathrm{B}_{\mathrm{M}}=$ Biomassa total model $\left(\mathrm{kg} \mathrm{ha}^{-1}\right)$

$\mathrm{k}_{\mathrm{m}}=$ Koefisien respirasi pemeliharaan

$\mathrm{k}_{\mathrm{g}} \quad=$ Koefisien respirasi pertumbuhan

$\eta_{x}=$ Proporsi Biomassa

$\mathrm{Bx}=$ Biomassa organ $\mathrm{x}$ (akar, batang, daun, dan tongkol).

Nilai koefisien respirasi pemeliharaan dan pertumbuhan yang digunakan pada penelitian ini berturutturut adalah sebesar 0,015 dan 0,14 (Handoko 1994). Sementara itu, untuk nilai parameter efisiensi penggunaan radiasi (RUE) dihitung berdasarkan data pengamatan aktual. Produktivitas jagung hasil model simulasi ditentukan dengan cara mengalikan proporsi tongkol terhadap nilai dugaan biomassa total dan kemudian dikalikan dengan proporsi pipilan jagung terhadap biomassa tongkol (Gambar 1).

\section{HASIL DAN PEMBAHASAN}

\section{Kondisi Cuaca Selama Penelitian}

Berdasarkan data pengamatan unsur cuaca selama musim tanam di lokasi penelitian menunjukkan bahwa curah hujan total selama penelitian tercatat sebesar
$745,74 \mathrm{~mm}$ dengan hari hujan sebanyak 57 hari, dan curah hujan harian tertinggi sebesar $53,34 \mathrm{~mm}$. Kondisi yang terjadi pada saat masa tanam merupakan musim hujan sehingga menyebabkan $75 \%$ dari keseluruhan masa tanam terjadi hujan (Gambar 2).

Suhu udara rata-rata, minimum, dan maksimum harian yang terdapat di wilayah tersebut berturut-turut adalah sebesar 31,$7 ; 34,4$; dan $27,1^{\circ} \mathrm{C}$ (Gambar 3). Radiasi total dalam satu hari dihitung menggunakan rumus penurunan sinus dari intensitas radiasi sesaat yang didapat dari hasil pengukuran. Intensitas radiasi terbesar selama penanaman jagung adalah $18 \mathrm{MJ} \mathrm{m}^{-2}$ hari ${ }^{-1}$ dan terkecil sebesar $3 \mathrm{MJ} \mathrm{m}^{-2}$ hari $^{-1}$ (Gambar 4).

\section{Biomassa Tanaman}

Hasil pengukuran biomassa total dan biomassa per tanaman menunjukkan bahwa biomassa tanaman jagung varietas Talenta lebih besar dibandingkan dengan varietas Bonanza-F1. Hal ini dipengaruhi oleh karakteristik pertumbuhan tiap varietas.

Biomassa per tanaman pada Gambar 5 menunjukkan bahwa semakin tinggi kerapatan tanaman maka biomassa per tanaman akan semakin rendah. Tanaman dengan kerapatan yang tinggi akan melakukan persaingan dalam mendapatkan unsur hara dan memanfaatkan radiasi yang diterima (Liu et al. 2004). Semakin rapat tanaman maka daun antar-tanaman akan saling menutupi sehingga radiasi yang diterima akan semakin sedikit. Petak percobaan yang memiliki kerapatan tanaman yang semakin tinggi mempunyai jumlah populasi tanaman yang semakin banyak. Dengan demikian, biomassa total akan semakin tinggi karena jumlah populasi berlaku sebagai faktor pengali dalam menentukan biomassa total.

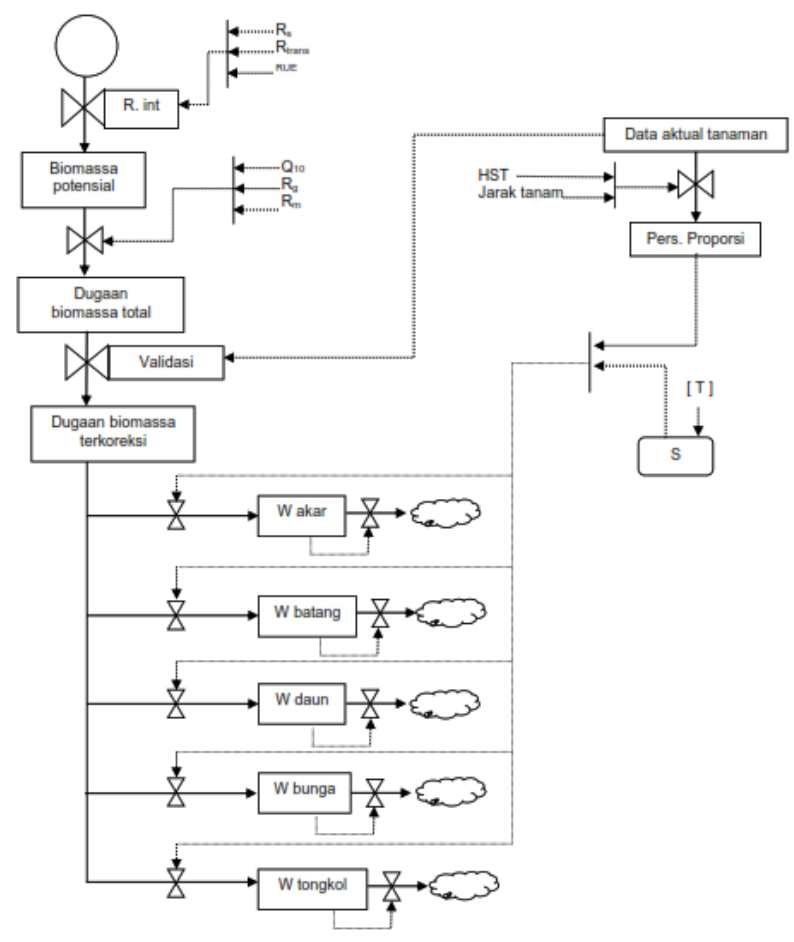

Gambar 1 Diagram forester submodel pertumbuhan tanaman. 


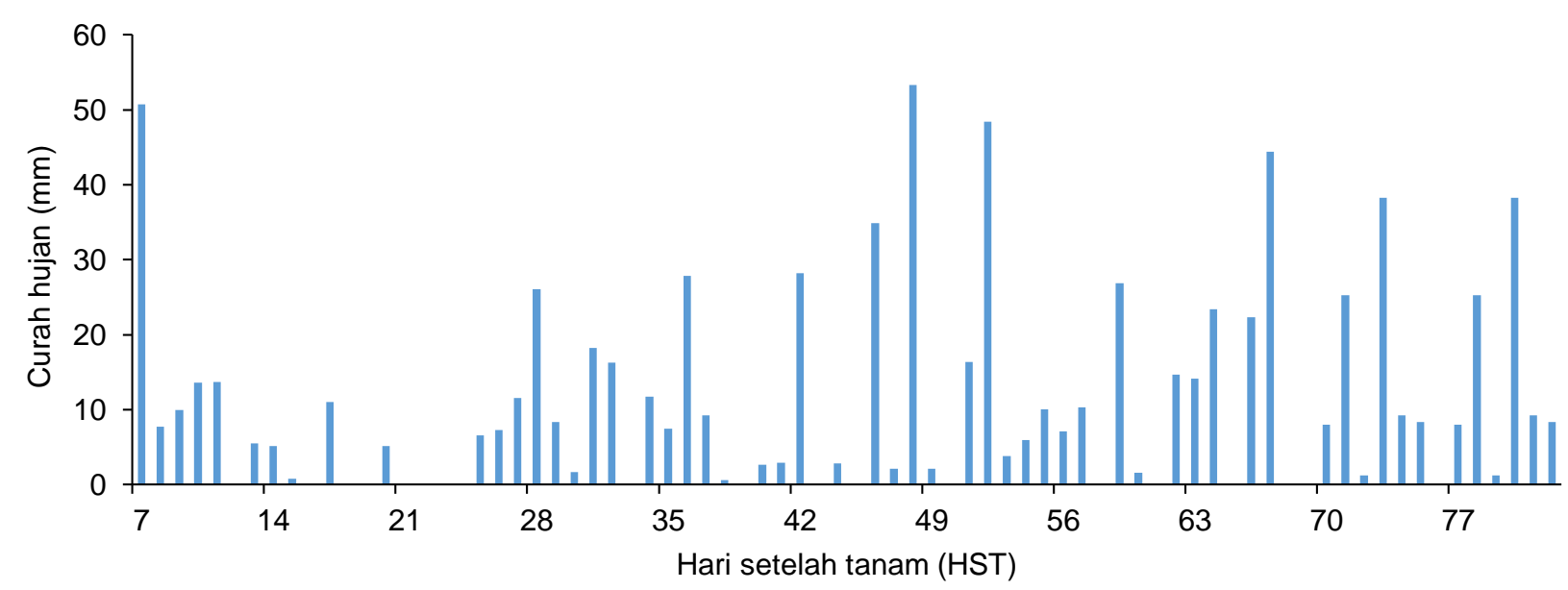

Gambar 2 Kondisi curah hujan selama penelitian.

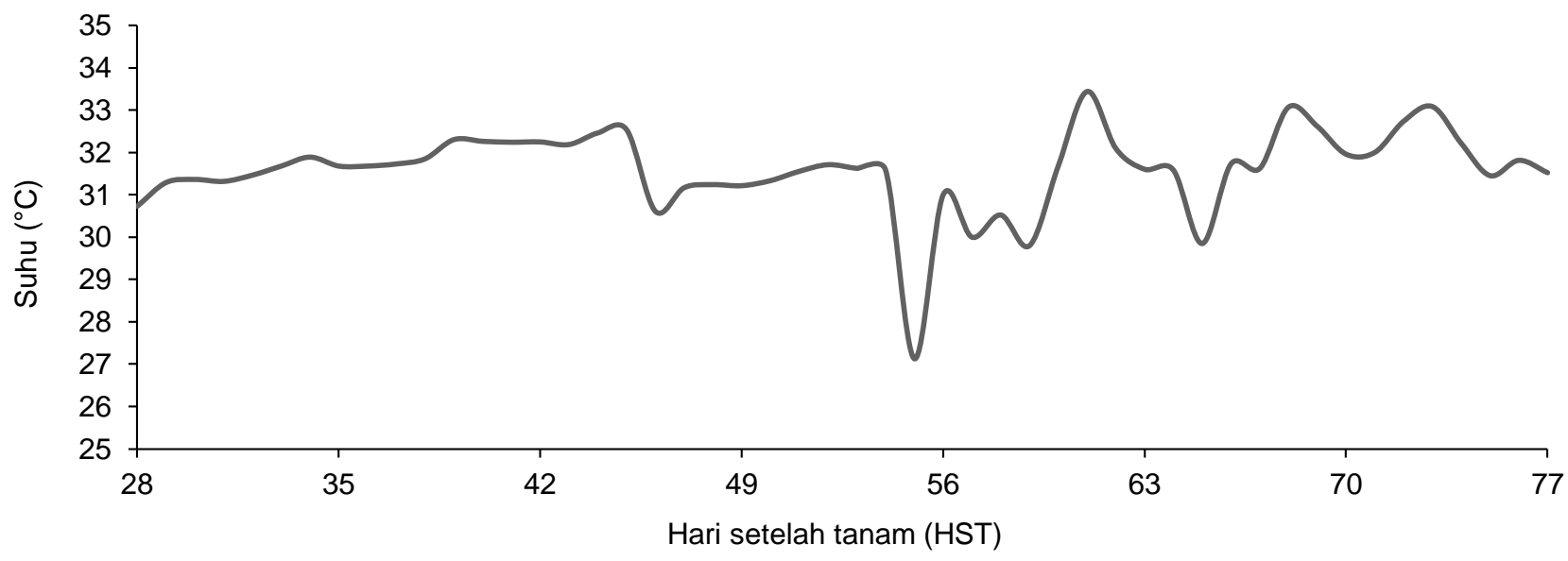

Gambar 3 Kondisi suhu udara rata-rata selama penelitian.

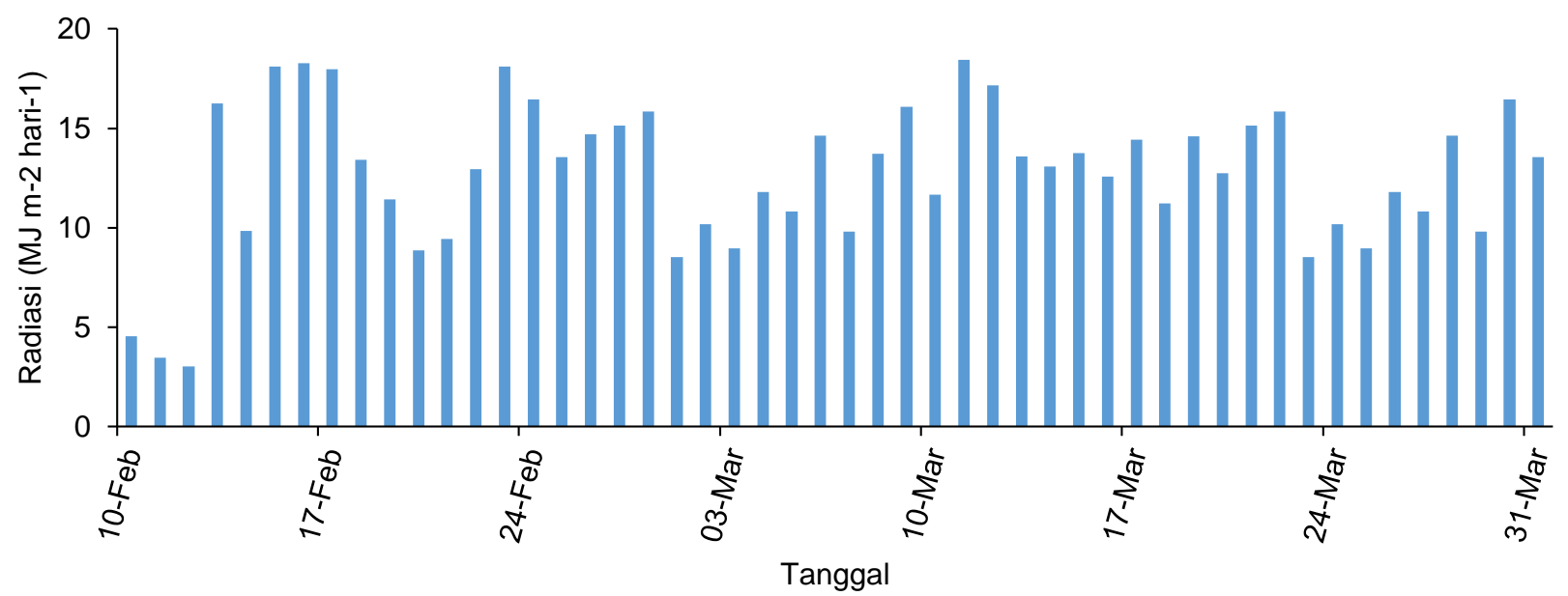

Gambar 4 Intensitas radiasi harian.

Biomassa total menunjukkan hasil yang berbeda dari biomassa per tanaman jika ditinjau dari segi jarak tanam. Jarak tanam yang lebih rapat pada kedua varietas memiliki biomassa total yang lebih besar dibandingkan dengan yang berjarak tanam lebih renggang (Gambar 6).

\section{Model Neraca Air Tanaman}

Hasil dari simulasi model neraca air tanaman pada lahan penelitian (kadar air tanah, $\mathrm{ET}_{0}$, dan $\mathrm{ET}_{\mathrm{c}}$ ) tersaji pada Gambar 7. Grafik tersebut menunjukkan bahwa nilai evapotranspirasi cenderung meningkat pada 7-25 HST dan kondisi curah hujan pada periode waktu tersebut rendah. Dengan demikian, ketersediaan air 

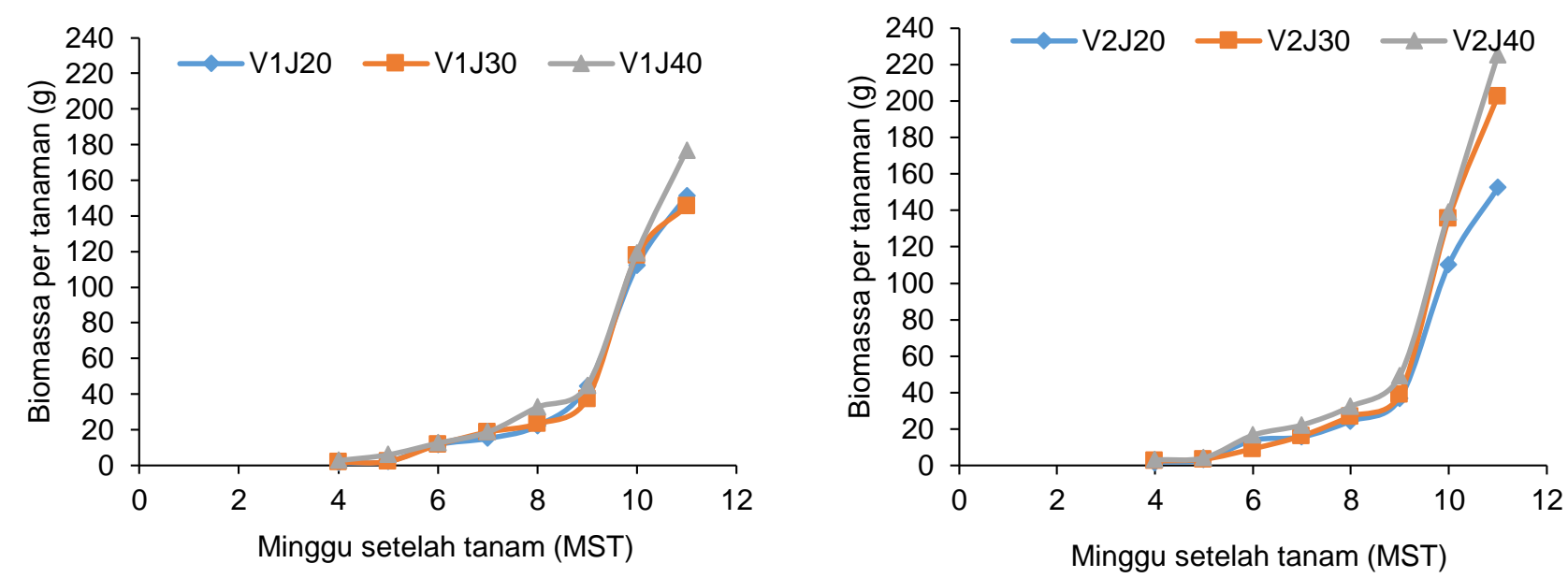

Gambar 5 Biomassa per tanaman.

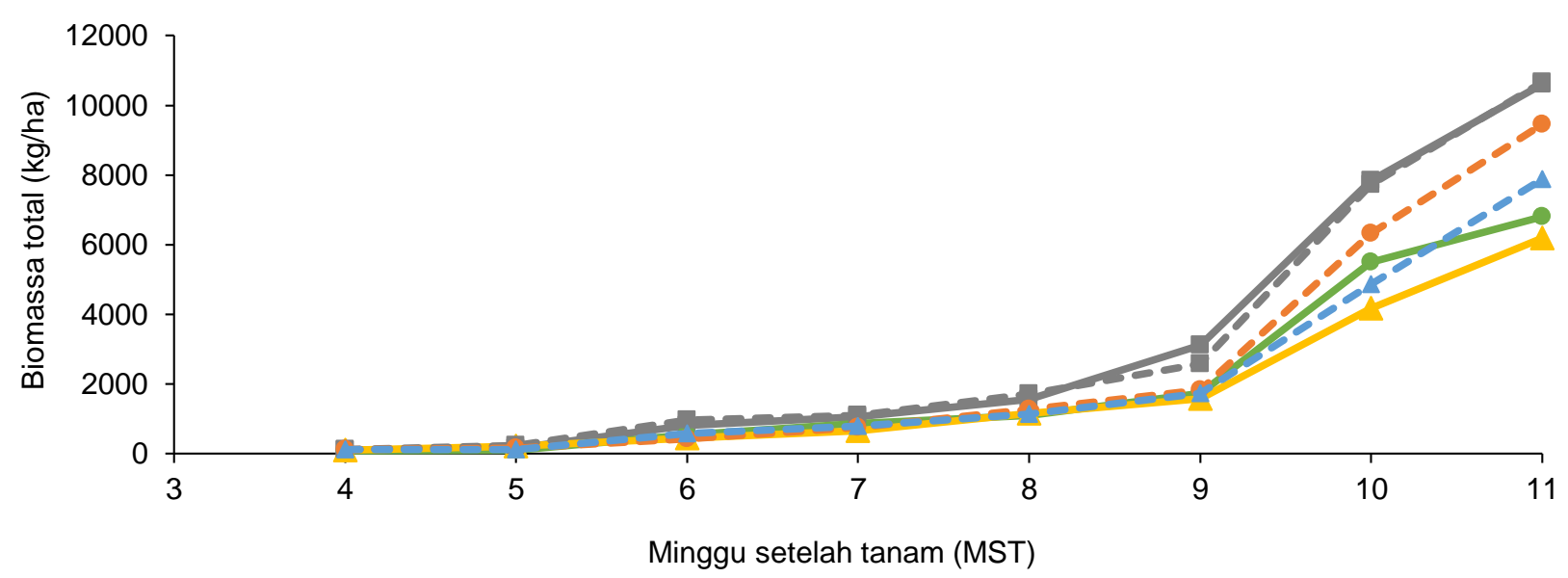

Gambar 6 Biomassa total aktual hasil pengukuran.

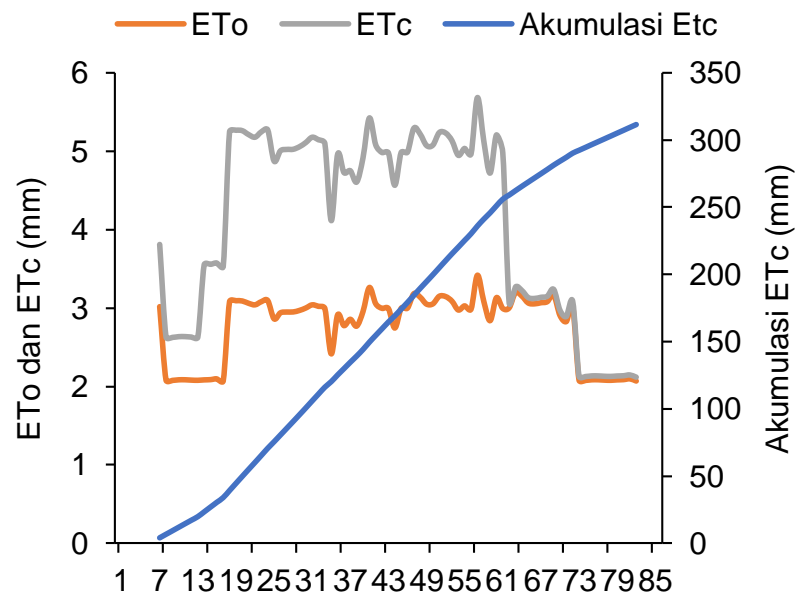

Hari setelah tanam (HST)

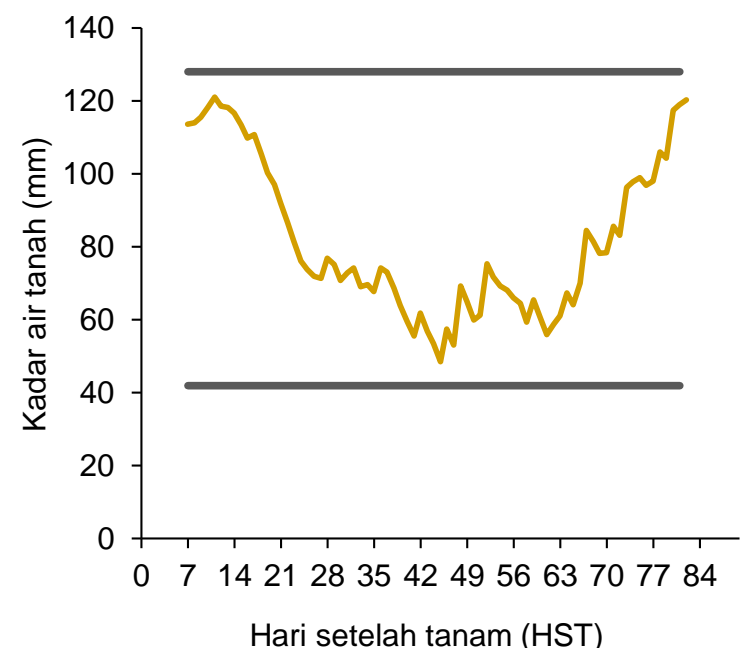

Hari setelah tanam (HST)

Gambar 7 Komponen neraca air selama musim pertumbuhan tanaman jagung.

tanah menurun. Pada saat 42-49 HST sempat terjadi kondisi kekurangan air. Namun demikian, sebagian besar tanaman mampu bertahan dalam cekaman tersebut. Berdasarkan model, nilai kadar air tanah masih berada di atas nilai titik layu permanen.

\section{Model Perkembangan Tanaman}

Nilai heat unit pada setiap fase perkembangan tersaji pada Tabel 1. Nilai heat unit yang berbeda pada kedua varietas menunjukkan bahwa waktu yang dibutuhkan untuk mencapai fase tersebut pun berbeda. 
Untuk mencapai fase berdaun tiga dan muncul bunga, varietas Bonanza-F1 membutuhkan waktu lebih lama satu minggu. Hal tersebut dapat terlihat dari nilai heat units yang lebih besar sehingga pada waktu yang sama pada saat varietas Talenta mulai berdaun tiga, varietas Bonanza-F1 masih mengutamakan pertumbuhan dan perkembangannya ke bagian akar dan batang.

Pengutamaan pertumbuhan dan perkembangan ke bagian akar dan batang oleh varietas Bonanza-F1 menyebabkan biomassa total varietas tersebut lebih besar pada saat itu. Hal tersebut dikarenakan bagian batang memiliki proporsi biomassa yang lebih besar. Perubahan fase perkembangan tanaman (s) akan terjadi jika akumulasi heat units (HU) tercapai untuk setiap fase. Berdasarkan rasio suhu rata-rata harian ( $\mathrm{T})$ dan suhu dasar $\left(\mathrm{T}_{0}\right)$, jagung dengan pertambahan heat unit setiap fase perkembangan maka didapatkan nilai pertambahan fase perkembangan harian $(\Delta s)$.

Grafik pada Gambar 8 menunjukkan bahwa titik fase berdasarkan pengamatan aktual berada dekat dengan garis simulasi. Dengan demikian, model ini dianggap mampu mensimulasi perkembangan tanaman dengan baik.

\section{Model Pertumbuhan Tanaman}

Nilai biomassa dugaan yang diperoleh dari hasil pemodelan mampu mendekati nilai biomassa aktual hasil pengamatan. Terlihat dari grafik yang terbentuk pada Gambar 9 bahwa nilai biomassa aktual hasil pengukuran masih berada pada rentang standard error nilai biomassa dugaan. Akan tetapi, pada beberapa perlakuan terdapat data biomassa aktual yang berada di luar rentang standard error.

Perlakuan V1J20 dan V2J20 menunjukkan bahwa nilai biomassa aktual berada di luar range (di atas nilai dugaan) pada saat 10 MST, sedangkan pada perlakuan V2J40 nilai biomassa aktual berada di luar range (di bawah nilai dugaan) pada saat $11 \mathrm{MST}$.

Grafik pada Gambar 10 menunjukkan bahwa terdapat hubungan yang linear antara nilai biomassa total hasil pemodelan dengan biomassa total aktual. Biomassa total hasil dugaan mampu menerangkan atau memprediksi nilai biomassa aktual sebesar 93\% dan sisanya sebesar $14 \%$ diterangkan oleh faktorfaktor lain. Hasil uji-t berpasangan menunjukkan nilai yang tidak berbeda nyata antara hasil simulasi dan hasil aktual pada semua perlakuan. Sementara itu, dari uji korelasi Pearson didapat nilai Pearson product moment lebih dari 0,90 dan mendekati nilai 1 (satu). Nilai tersebut menurut Sugiyono (2007) termasuk kategori sangat kuat.

\section{Proporsi Biomassa Tanaman}

Pendugaan nilai proporsi biomassa organ tanaman dibutuhkan untuk kepentingan pemodelan. Hasil pengukuran proporsi biomassa organ tanaman secara aktual pada enam kombinasi perlakuan menunjukkan adanya potensi hubungan antara jarak tanam yang digunakan serta umur tanaman dan nilai proporsi. Dengan demikian, dapat disusun persamaan berdasar-

Tabel 1 Parameter perkembangan tanaman jagung pada jarak tanam $70 \times 30 \mathrm{~cm}$

\begin{tabular}{|c|c|c|c|c|}
\hline \multirow[t]{2}{*}{ Fase perkembangan } & \multicolumn{2}{|c|}{ Bonanza-F1 } & \multicolumn{2}{|c|}{ Talenta } \\
\hline & $\mathrm{HU}\left(\mathrm{d}^{\circ} \mathrm{C}\right)$ & Total & $\mathrm{HU}\left(\mathrm{d}^{\circ} \mathrm{C}\right)$ & Total \\
\hline Semai-perkecambahan $\left(\mathrm{HU}_{\mathrm{k}}\right)$ & 93 & 93 & 93 & 93 \\
\hline Perkecambahan-Berdaun tiga $\left(\mathrm{HU}_{\mathrm{v} 3}\right)$ & 239 & 332 & 239 & 332 \\
\hline Berdaun tiga-Berdaun enam $\left(\mathrm{HU}_{\mathrm{v} 6}\right)$ & 327 & 659 & 237 & 569 \\
\hline Berdaun enam-Berdaun sembilan ( $\left.\mathrm{HU}_{\mathrm{v} 9}\right)$ & 376 & 1035 & 323 & 892 \\
\hline Berdaun sembilan-Muncul bunga ( $\left.\mathrm{HU}_{\mathrm{b}}\right)$ & 121 & 1156 & 121 & 1013 \\
\hline Muncul bunga-Pembentukan buah ( $\left.\mathrm{HU}_{\mathrm{pb}}\right)$ & 242 & 1398 & 265 & 1278 \\
\hline Pembentukan buah-Biji susu (HUbs) & 347 & 1745 & 358 & 1636 \\
\hline Biji susu-Biji masak susu (HUms) & 120 & 1865 & 182 & 1818 \\
\hline
\end{tabular}

Keterangan: $\mathrm{HU}=$ Heat units.

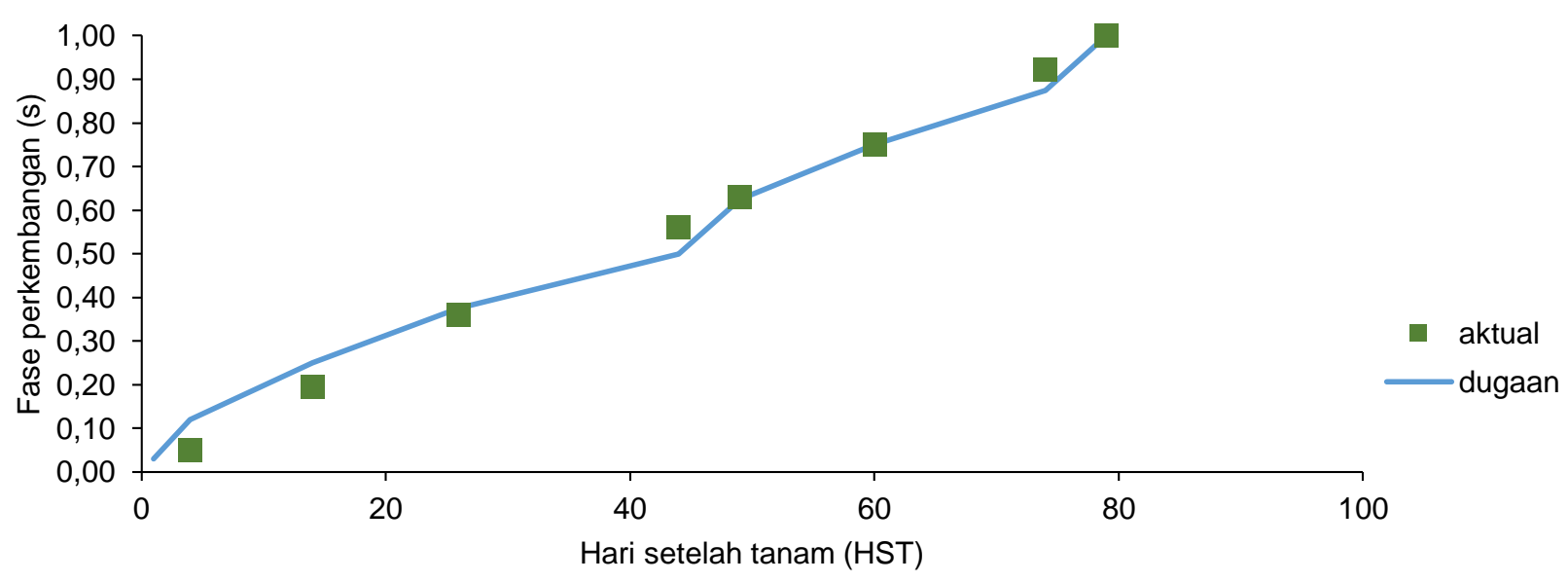

Gambar 8 Skala fase perkembangan tanaman. 

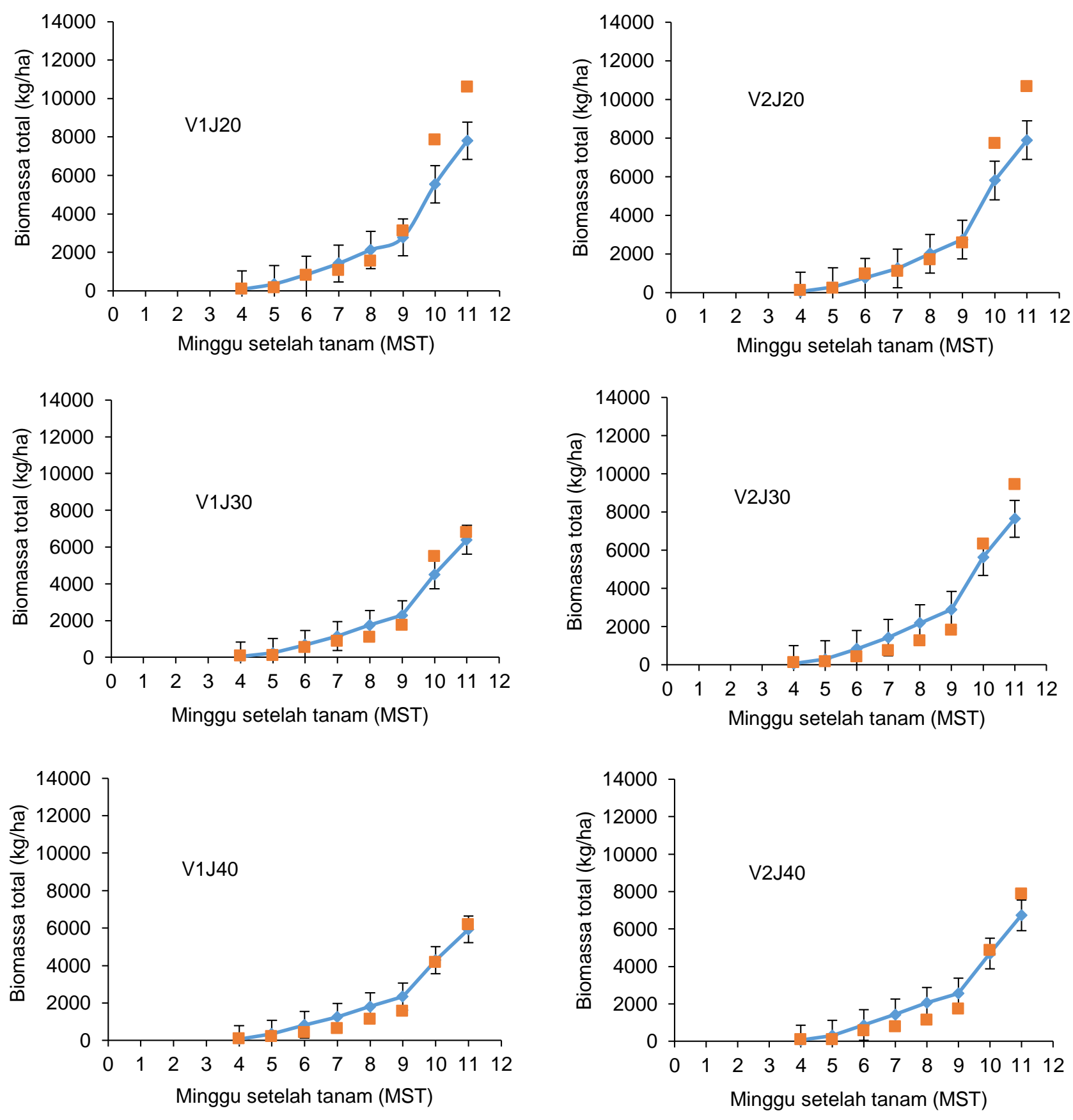

Gambar 9 Perbandingan nilai biomassa total dugaan (-) dengan aktual (匹).

kan regresi linear berganda untuk menduga nilai proporsi (Tabel 2).

Persamaan proporsi disusun berdasarkan fase yang terjadi selama musim tanam. Fase pada tanaman Bonanza-F1 dan Talenta dikelompokkan berdasarkan dua fase utama, yaitu fase vegetatif dan fase generatif. Untuk Bonanza-F1, tahap vegetatif terjadi pada saat tanaman berumur $<56$ HST dan tahap generatif terjadi pada saat umur tanaman $>56 \mathrm{HST}$. Sementara itu, fase vegetatif pada Talenta terjadi pada saat tanaman berumur <49 HST dan tahap generatif terjadi pada saat umur tanaman $>49$ HST.

Tanaman jagung Talenta lebih dulu mencapai vase generatifnya dan hal ini berkesesuaian dengan hasil penelitian Cahya \& Ninuk (2018) yang menyatakan bahwa dengan perlakuan yang sama varietas Talenta akan lebih dahulu mencapai fase generatifnya dibanding dengan varietas Bonanza- $\mathrm{F} 1$. Varietas Talenta mulai berbunga pada umur $>49 \mathrm{HST}$, sedangkan varietas Bonanza berbunga pada 55-60 HST (Cahya \& Ninuk 2018).

\section{Produktivitas Jagung}

Hasil dugaan produktivitas jagung tersaji pada Tabel 3. Dugaan produktivitas menunjukkan kisaran angka antara $3171-5143 \mathrm{~kg} / \mathrm{ha}$, sedangkan dari hasil pengukuran langsung menunjukkan kisaran angka $3076-4258 \mathrm{~kg} / \mathrm{ha}$. Nilai produktivitas jagung wilayah 


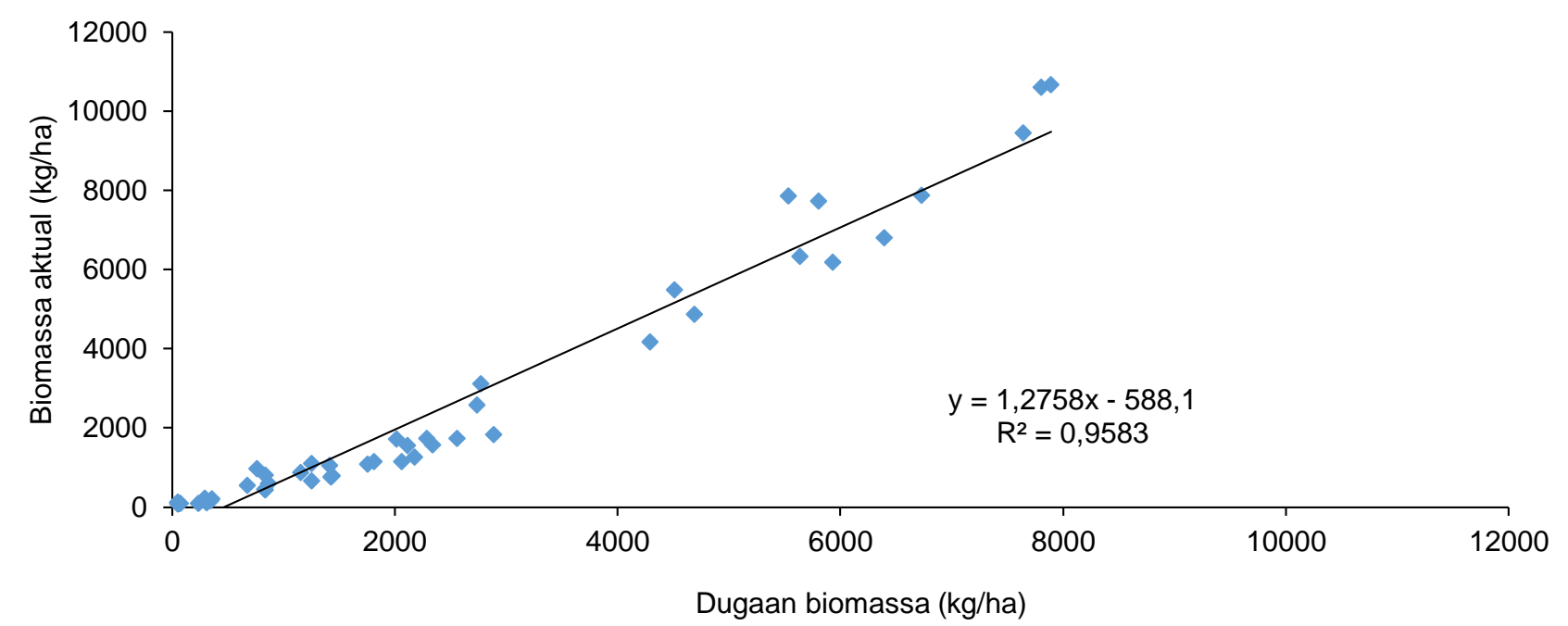

Gambar 10 Hubungan antara nilai dugaan biomassa dengan biomassa aktual.

Tabel 2 Persamaan berdasarkan regresi linier berganda untuk menduga nilai proporsi

\begin{tabular}{|c|c|}
\hline \multicolumn{2}{|c|}{ Bonaza } \\
\hline HST $<=56$ & $\mathrm{HST}(\mathrm{i})>56$ \\
\hline $\mathrm{Pb}(\mathrm{i})=0,25 * \mathrm{HST}(\mathrm{i})+0,8852$ * J & $\mathrm{Pb}(\mathrm{i})=0,23 * \mathrm{HST}(\mathrm{i})+0,43 * \mathrm{~J}$ \\
\hline $\operatorname{Pd}(\mathrm{i})=1,19 * \mathrm{HST}(\mathrm{i})+0,28 * \mathrm{~J}$ & $\mathrm{Pd}(\mathrm{i})=0,16 * \mathrm{HST}(\mathrm{i})+0,22 * \mathrm{~J}$ \\
\hline $\operatorname{Pf}(\mathrm{i})=0$ & $\operatorname{Pf}(i)=-0,061 * \operatorname{HST}(i)+0,314 * \mathrm{~J}$ \\
\hline $\mathrm{Pt}(\mathrm{i})=0$ & $\mathrm{Pt}(\mathrm{i})=3,477^{*} \mathrm{HST}(\mathrm{i})-0,0157 * \mathrm{~J}-198,86$ \\
\hline $\mathrm{Pa}(\mathrm{i})=0,0432 * \mathrm{HST}(\mathrm{i})+0,0271$ * J & $\mathrm{Pa}(\mathrm{i})=-0,392 * \mathrm{HST}(\mathrm{i})-0,038 * \mathrm{~J}+32,976$ \\
\hline \multicolumn{2}{|c|}{ Talenta } \\
\hline HST(i) $<=49$ & HST(i) $>49$ \\
\hline $\mathrm{Pb}(\mathrm{i})=0,665$ * $\mathrm{HST}(\mathrm{i})+0,206$ * J & $\mathrm{Pb}(\mathrm{i})=0,304$ * $\mathrm{HST}(\mathrm{i})+0,336$ * J \\
\hline $\operatorname{Pd}(\mathrm{i})=0,604{ }^{*} \mathrm{HST}(\mathrm{i})+0,879 * \mathrm{~J}$ & $\operatorname{Pd}(\mathrm{i})=-1,009 * \mathrm{HST}(\mathrm{i})-0,099 * \mathrm{~J}+91.8$ \\
\hline $\operatorname{Pf}(i)=0$ & $\operatorname{Pf}(\mathrm{i})=-0,016 * \mathrm{HST}(\mathrm{i})+0,2 * \mathrm{~J}$ \\
\hline $\operatorname{Pt}(\mathrm{i})=0$ & $\operatorname{Pt}(\mathrm{i})=2,95 * \mathrm{HST}(\mathrm{i})+0,52 * \mathrm{~J}-175.098$ \\
\hline $\mathrm{Pa}(\mathrm{i})=0,243$ * $\mathrm{HST}(\mathrm{i})+0,164$ * J & $\mathrm{Pa}(\mathrm{i})=-0,588$ * HST $(\mathrm{i})-0,077^{*} \mathrm{~J}+47.687$ \\
\hline
\end{tabular}

Keterangan: $\mathrm{Pb}=$ Proporsi batang, $\mathrm{Pa}=$ Proporsi akar, $\mathrm{Pd}=$ Proporsi daun, $\mathrm{Pt}=$ Proporsi tongkol, $\mathrm{J}=\mathrm{Jarak}$ tanam, $\mathrm{Pf}=$ Proporsi bunga, dan HST $=$ Hari setelah tanam.

Tabel 3 Produktivitas jagung hasil model, aktual, data BPS, dan survei petani

\begin{tabular}{ccrrcr}
\hline & Jarak & \multicolumn{4}{c}{ Pipilan kering (kg/ha) } \\
\cline { 3 - 4 } & $\begin{array}{c}\text { tanam } \\
(\mathrm{cm})\end{array}$ & Model & Aktual & BPS & Petani \\
\hline \multirow{3}{*}{ Bonanza } & $70 \times 20$ & 4142 & 4258 & & \\
& $70 \times 30$ & 3171 & 3076 & & \\
& $70 \times 40$ & 3048 & 2864 & 4427 & 4226 \\
\multirow{3}{*}{ Talenta } & $70 \times 20$ & 5143 & 4225 & & \\
& $70 \times 30$ & 4626 & 3733 & & \\
& $70 \times 40$ & 4447 & 3638 & & \\
\hline
\end{tabular}

Kabupaten Subang adalah $4427 \mathrm{~kg} / \mathrm{ha}$ (BPS Subang 2016). Selain itu, berdasarkan hasil survei kepada petani setempat bahwa rata-rata produktivitas jagung adalah sebesar $4226 \mathrm{~kg} / \mathrm{ha}$. Dengan demikian, dapat dikatakan bahwa model simulasi produktivitas jagung berada pada kisaran nilai pengukuran maupun data BPS dan survei petani.

\section{KESIMPULAN}

Pertumbuhan, perkembangan, dan produksi tanaman jagung hibrida dipengaruhi oleh penerimaan radiasi. Jarak tanam yang berbeda memengaruhi penerimaan radiasi oleh tanaman akibat faktor kerapatan dan penutupan antar-daun. Jarak tanam 70 x $20 \mathrm{~cm}$ mampu mengintersepsi radiasi matahari $12 \%$ lebih besar dari jarak tanam $70 \times 30 \mathrm{~cm}$ dan jarak tanam $70 \times 30 \mathrm{~cm}$ mampu mengintersepsi radiasi matahari $7 \%$ lebih besar dari jarak tanam $70 \times 40 \mathrm{~cm}$. Pertumbuhan dan perkembangan tanaman dapat disimulasikan melalui submodel pertumbuhan dan submodel perkembangan. Model pertumbuhan dan perkembangan tanaman jagung manis hibrida mampu menduga biomassa tanaman, fase perkembangan, dan produktivitas dan tidak berbeda nyata dibandingkan dengan hasil aktual pada kondisi karakteristik iklim dan cuaca yang sama. 
Jarak tanam yang disarankan untuk menanam jagung manis hibrida berdasarkan model adalah jarak tanam $70 \times 20 \mathrm{~cm}$ dengan menggunakan varietas Talenta. Perlu dilakukan validasi model dengan melakukan percobaan di lokasi yang memiliki karakteristrik iklim dan cuaca yang berbeda agar model dapat diaplikasikan secara lebih luas.

\section{UCAPAN TERIMA KASIH}

Penulis mengucapkan terima kasih kepada Ahmad Shalahudin S.Si yang sudah membantu dalam pembuatan alat dan penyusunan model. Penulis juga mengucapkan terima kasih kepada Shinta Indriyani S.Pd atas bantuannya selama proses penanaman hingga panen.

\section{DAFTAR PUSTAKA}

Apriyantono A. 2011. Deskripsi jagung manis varietas Bonanza-F1. Kementerian Pertanian. Jakarta (ID): $24 \mathrm{hlm}$.

Bahar Y. 2009. Model Simulasi Tanaman Jagung. [skripsi]. Bogor (ID): Institut Pertanian Bogor.

[BPS] Badan Pusat Statistik Kabupaten Subang. 2016. Kabupaten Subang dalam angka 2016. Subang (ID): Badan Pusat Statistik Kabupaten Subang.

Cahya JE, Ninuk H. 2018. Uji Potensi Enam Varietas Jagung Manis (Zea mays saccharata Sturt) di Dataran Rendah Kabupaten Pamekasan. Jurnal Produksi Tanaman. 6: 92-100.

Haith DA, Shoemaker LL. 1987. Generalized watershed loading functions for stream flow nutrients. Water Resources Bulletin. 23: 471-478. https://doi.org/10.1111/j.1752-1688.1987.tb00 825. $x$

Handoko. 1994. Dasar Penyusunan dan Aplikasi Model Simulasi Komputer untuk Pertanian. Bogor (ID): Geomet FMIPA-IPB.

Kementan. 2016. Juknis Gerakan Pengembangan Jagung Hibrida. Jakarta (ID): Kementrian Pertanian.

Kiniry JR, Jones CA, O'Toole, Blanchet R, Cabelguene M, Spanel DA. 1989. Radiation use efficiency in biomassa accumulation prior to grain filling for five grain-crop species. Field Crops Research. 20 : 51-64. https://doi.org/10.1016/0378-4290(89)900 23-3

Koesmaryono Y. 1996. Studies on Photosynthesis, Growth and Yield of Soybean (Glycine max
(L.)Merr.) in Relation to Climatological Envirotment. [Dissertation]. Matsuyama (JP): Ehime University.

Liu W, Tollenaar M, Stewart G, Deen W. 2004. WithinRow Plant Spacing Variability Does Not Effect Corn Yield. Agronomy Journal. 96: 275-280. https:// doi.org/10.2134/agronj2004.2750

Muamar, Triyono S, Tusi A, Rosadi B. 2012 Analisis Neraca Air Tanaman Jagung (Zea Mays) Di Bandar Lampung. Jurnal Teknik Pertanian Lampung. 1: $1-10$

Mulyani A, Dariah A, Nurida NL, Sosiawan H, Las I. 2014. Penelitian dan pengembangan pertanian di lahan suboptimal lahan kering iklim kering: Desa Mbawa, Kecamatan Donggo, Kabupaten Bima, Provinsi NTB. Makalah Seminar Ilmiah Sistem Riset Inovasi Nasional (InSinas 2014), Kemenristek, Bandung (ID): 1-2 Oktober 2014.

Paat JF. 2010. Model Pertumbuhan dan Produksi Jagung Hibrida Pada Perlakuan Pemberian Nitrogen Serta Pemangkasan Tassel. Jurnal Eugenia. 16: 228-236. https://doi.org/ 10.35791/eug.16.3.2010.7139

Paski JAI, Faski GISL, Handoyo F, Pertiwi DAS. 2017. Analisis Neraca Air Lahan untuk Tanaman Padi dan Jagung di Kota Bengkulu. Jurnal Ilmu Lingkungan. 15. 83-89. https://doi.org/10.14710/ jil.15.2.83-89

Pusat Kajian Hortikultura Tropika. 2011. Konsumsi Perkapita Hortikultura. Bogor (ID): Institut Pertanian Bogor.

Tahir M, Tanveer A, Ali A, Abbas M, Wasaya A. 2008. Comparative Yield Performance of Differential Maize (Zea Mays L.) Hybrid under Local Conditions of Faisalabad-Pakistan. Pakistan Journal of Life and Social Sciences. 6: 118-120.

Qadir A. 2012. Pemodelan pertumbuhan tanaman kedelai (Glycine max (L.) Merrill) di bawah cekaman naungan [disertasi]. Bogor (ID): Institut Pertanian Bogor. $93 \mathrm{hlm}$.

Sugiyono. 2007. Metode Penelitian Administrasi. Bandung (ID): Alfabeta.

Sumajow AYM, Rogi JEX, Tumbelaka S. 2016 Pengaruh Pemangkasan Daun Bagian Bawah Terhadap Produksi Jagung Manis. Jurnal AGRISOSIOEKONOMI. 12: 65-72. https://doi.org/ 10.35791/agrsosek.12.1A. 2016.11537

Suwarto. 2005. Model pertumbuhan dan produksi jagung dalam tumpang sari dengan ubi kayu [disertasi]. Bogor (ID): Institut Pertanian Bogor. 